
w Warszawie gszwat@ispan.waw.pl

\title{
Aleksandra Kiosewa koncepcja samokolonizacji i efekt symmorfozy*
}

\begin{abstract}
Szwat-Gyłybowa Grażyna, Aleksandra Kiosewa koncepcja samokolonizacji i efekt symmorfozy (Alexander Kiosev's Concept of Self-colonization and the Symmorphic Effect). "Poznańskie Studia Slawistyczne" 13. Poznań 2017. Publishing House of the Poznań Society for the Advancement of the Arts and Sciences, pp. 33-46. ISSN 2084-3011.

Stemming from the general postcolonial theoretical tradition, the concept of self-colonisation proposed by the Bulgarian scholar Alexander Kiosev has proved inspiring to Polish scholars. This article attempts to examine more closely Kiosev's meandering self-reflective musings on what he called his "metaphor" of self-colonization, an idea he ultimately rejected in view of the undesirable ressentiment it tends to produce. By illustrating the historical and cultural background underpinning the concept of self-colonisation I seek to identify the roots of potential intercultural misunderstanding. Above all, I focus on the consequences of the teleological approach inherent in Kiosev's concept. Those are expressed in identifying manufactured (sic!) origins with an account which can be couched in the language of a politically and therapeutically conditioned method of research. This leads to a symmorphic deformation of those origins, aligned to the requirements of the modern world.
\end{abstract}

KEYwORDS: Bulgarian culture; self-colonisation; origins; teleology; symmorphosis; ressentiment

W głośnej w Polsce przed kilku laty książce Fantomowe ciało króla. Peryferyjne zmagania z nowoczesna forma (2011) Jan Sowa, budując swą na poły naukową, na poły mitotwórczą narrację na temat ustanawiania polskiej nowoczesności, oparł tok rozumowania na kilku strategiach metodologicznych, m.in. na koncepcji samokolonizacji kultur peryferyjnych, której autorem jest bułgarski badacz Alexander Kiossev (Aleksander Kiosew $\left.{ }^{1}\right)$. Sowa szukał wyjaśnienia polskich ,zmagań z nowoczesną formą”

${ }^{*}$ This work was supported by a grant from National Science Centre in Poland (decision No. 2014/13/B/HS2/01057).

${ }^{1} \mathrm{~W}$ polskiej literaturze przedmiotu jego nazwisko jest dwojako transliterowane z cyrylicy. Ja sama stosować będę dalej zapis Aleksander Kiosew. 
zarówno w historii gospodarki i ustroju Pierwszej Rzeczpospolitej, jak i w sferze zbiorowych fantazmatów i (w ślad za Lacanem) wciąż powracającego nieświadomego. Choć trudno odmówić jego książce wizjonerskiego rozmachu, zwłaszcza w rozdziałach odsłaniających (w nawiązaniu do teologii politycznej Ernsta H. Kantorowicza²) domniemaną fantomowość władzy królewskiej w Polsce szlacheckiej, to jego argumentacja na rzecz polskiego stygmatu postkolonialnego wydaje się chybiona o tyle, że w najgłębszej osnowie strategia opisu (a więc nadawania formy) oraz wnioskowania (nazywania sensu i funkcji) została oparta na międzykulturowym nieporozumieniu, a zarazem na wspólnym przedsądzie badaczy na temat relacji peryferie - centrum. Kiosew nadał swej koncepcji kształt jeśli nie uniwersalny, to w każdym razie na tyle oczyszczony z partykularnych atrybutów, by ta mogła znaleźć zastosowanie również w odniesieniu do obszaru niebułgarskiego, a tym samym pośrednio przysłużyć się do zniesienia z kultury bułgarskiej stygmatu niechcianej wyjątkowości, „,nie dość egzotycznej egzotyki”. Nie wskazał przy tym żadnego - poza Bułgarią - kraju, który zostałby przezeń zaklasyfikowany jako samokolonizujący się. Brak konkretyzacji i punktów odniesienia otworzył możliwość swobodnych funkcjonalizacji metafory Kiosewa w dyskursach naukowych ${ }^{3}$ i publicystycznych. Niektóre z nich u samego badacza mogłyby wywołać dysonans poznawczy, jak np. narracja polskiej eurosceptyczki, która posłużyła się konceptem samokolonizacji w odniesieniu do ówczesnych starań Polaków o akcesję do Unii Europejskiej (Kasprzyk, 2000, 196-199). Polscy humaniści (w tym pisząca te słowa) metaforę samokolonizacji podejmowali, nie przypatrując się być może wystarczająco uważnie meandrom naukowej autokorekty Kiosewa.

\section{Samokolonizacja. Formatowanie genealogii}

Koncepcja samokolonizacji, wyrosła z myśli postkolonialnej, została najszerzej przedstawiona przez Aleksandra Kiosewa w rozprawie Списъии

${ }^{2}$ Chodzi o jego słynną książkę Dwa ciała króla. Studium ze średniowiecznej teologii politycznej (2007). Pierwsze wydanie angielskojęzycznego oryginału miało miejsce w 1957 roku!

${ }^{3}$ Sama ulegałam jej uruchamiającemu wyobraźnię urokowi m.in. w swojej książce Haeresis bułgarica w bułgarskiej świadomości kulturowej XIX i XX wieku (2005). 
на отсъствието (1998) ${ }^{4}$. Przedstawiona i jeszcze w tym samym tekście porzucona (Кьосев, 1998, 22), ponieważ autor potraktował ją jako metaforę wyjściową do dalszych rozważań na temat genealogii sporów dotyczących bułgarskiej spuścizny literackiej (fetyszyzowanej w drugiej połowie XIX i na początku XX wieku), dotyczących „posiadania” bądź też „nieposiadania literatury”. Koncepcja samokolonizacji powstała na podstawie bułgarskich doświadczeń modernizacji. Posługując się koncepcją narodu jako wspólnoty wyobrażonej Andersona, narzędziami psychoanalizy (z naciskiem na Lacana) i krytyki postkolonialnej, Kiosew sformułował hipotezę, że doświadczenie braku, niedostatku form kultury uznanych przez jakąś wspólnotę za uniwersalne w momencie kluczowym dla zwrotu modernizacyjnego, legło u podstaw wielu kształtujących się wówczas tożsamości narodowych:

(...) възникването на тези нации е свързано с опреденлена икономика на символите: и от тази гледна точка само-колонизиращи се култури изглеждат така, сякаш те сами пренасят един цужд ценностен и цивилизационен модел и любовно колонизират с него Своето (Кьосев, 1998, 11).

(...) само-колонизиращи се култури извършват едно голямо заместване - те внасят символите и моделите на Чъждото на мястото, което е било запазено за Трансцендентното и Същностното. (...) В контраст с нарцистъчната идеология на Запада, самоколонизиращите се култури страдат от един трагичен парадокс - за тях Чуждото се оказва Универсално, но и обратното е вярно - Универсалното е винаги Чуждо (Кьосев, 1998, 12).

W świetle tego ujęcia kulturowa i mentalna specyfika krajów „,samokolonizujących się” daje się zrozumieć jako perwersyjna autoagresja kulturowa, symboliczna przemoc narzucana sobie samym pod wpływem frustracji z powodu ustanowionego ,braku” i bałwochwalczej wiary w wyższość obcych, a podających się za „uniwersalne”, wartości. Kiosew zakładał możliwość szerokiego stosowania metafory samokolonizacji w odniesieniu do tych krajów, w których proces nadawania formy imaginarium kultury narodowej wyrastać miał z takiego właśnie doświadczenia i urzeczywistniał się w warunkach ciążenia tego, co partykularne i niepełne ku temu, co uniwersalne i pełne:

${ }^{4}$ Dostępny jest polski przekład fragmentów tej rozprawy (Kiosew, 2000). Sowa korzystał z angielskiego przekładu (Kiossev, 1999). 
Но всичко казано до тук не може, разбира се, да се отнесе само единствено до българската култура. Кои тогава са културите, които тук наричаме със странните маетафори „само-колонизарщи се“, „култури на отсъсвието”?

В перспектива на една глобализираща се световна история, има култури, които изглеждат недостатъчно централни и универсални, недостатъчно навреммени, недостатъчно големи. Заедно с това те се оказват недостатъчно чужди, недостатъчно далечни и недостатъчно изостанали по отночение на „централните и големи” нации (...) (Кьосев, 1998, 11-12).

Tym, co zainteresowało Jana Sowę i czemu de facto poświęcił swoją książkę, było pragnienie dotarcia do holistycznie rozumianej genezy ,polskiej formy nowoczesnej". Eksploracja materiału doprowadziła go do rozpoznania faktu, że w kulturze polskiej:

(...) to, co niższe, podporządkowane czy uzależnione, ukonstytuowało się jako takie właśnie i nie istniało, zanim nie zostało poddane owemu procesowi podporządkowania. Dlatego wyzwoleniem od kondycji peryferyjnej (samo)kolonizacji (...) nie może być powrót do matecznika własnej świetności sprzed kolonizacji, ale odczytanie we własnej partykularnej kondycji ruchu tego, co uniwersalne. (...) To, co uniwersalne, i to, co partykularne, nie znajduje się więc w relacji antagonistycznej, jak się często wydaje nacjonalistom, ale w relacji symbiotycznej, dlatego nie daje się skutecznie rozegrać jednego przeciw drugiemu (Sowa, 2011, 533-534).

Choć na poziomie intuicji naukowej pod wieloma względami trudno nie zgodzić się z Sową, to jednak rozpisana na wielu stronach książki rekonstrukcja procesu ustanawiania nowoczesnej tożsamości Polaków w części konceptualnie powiązanej z samokolonizacją sprawia wrażenie nadinterpretacji, opartej na takiej puryfikacji danych, aby dały się wtłoczyć w gotową formę, skrojoną na inną miarę. Kompleks braku instytucji, o którym w pierwszej części rozprawy pisał Kiosew, wychwycony został przez badacza na podstawie analizy sytuacji geokulturowej, która w sposób fundamentalny różniła się od polskiej. Modernizacja kultury bułgarskiej odbywała się w drodze całkowitej zmiany modelu cywilizacyjnego z osmańskiego na zachodni i od lat 30. XIX wieku przebiegała w trudnych warunkach „europeizowania się” samej Turcji w epoce Tanzymatu. Dość powiedzieć, że jeszcze w drugiej połowie XIX wieku noszenie osmańskiego fezu zamiast kołpaka uchodziło w Bułgarii za symbol modernizacji.

Trochę dziwić może fakt, że akt ustanawiania nowego typu posesywności przez samoformujący się bułgarski naród Kiosew przedstawił jako jądro zmiany kulturowej, której celem było wprowadzenie wartości kojarzonych 
z Obcym (w tym wypadku Zachodem) w miejsce sakralnie pojmowanej swojskości. Ten psychoanalityczny aspekt refleksji Kiosewa wydaje się wątpliwy dlatego, że konstatacje odnoszą się do zbiorowości historycznie definiowanej w sposób niepewny i opierają się na bardzo małej liczbie źródeł. Piśmiennictwo cerkiewne bułgarskiego „czasu siodła" ${ }^{5}$ mówi na ten temat niewiele lub wcale, a troska prawosławnych duchownych o obyczajność i ich lęk przed narastającą liczbą dobrowolnych konwersji na islam świadczą o problemach bułgarskojęzycznej prawosławnej wspólnoty religijnej z utrzymaniem własnej koherencji. Z kolei wiarygodność innego kompleksu źródeł historycznych, którym jest folklor, pozostaje względna; muszą być one czytane według określonego klucza, tym bardziej że na fali XIX-wiecznego zbieractwa podlegały wielu korektom ze strony ideologicznie zapętlonych kolekcjonerów. W tej sytuacji i sama „swojskość”, i sugerowany przez Kiosewa typ autorefleksji pozostają hipotezą nie do udowodnienia z powodu braku źródeł. Jedyny tekst „autobiograficzny” z tego okresu to dziełko biskupa Wracy Żywot i cierpienia grzesznego Sofroniusza (1806). Pod tym względem sprawy zaczynają się zmieniać dopiero w latach 40. XIX wieku, kiedy to reformy Tanzymatu w imperium osmańskim są już w toku, a w ślad za politycznym usamodzielnieniem się Serbów i Greków zaczynają się pojawiać zalążki bułgarskich aspiracji narodowych oraz piśmiennictwo podejmujące (zgodnie z utylitarnym rytem epoki) ważkie dla kształtującej się wspólnoty tematy (jak język literatury, szkolnictwo, autokefalia, nauka). W tym czasie kompleksotwórcze konstatacje, o których mówi Kiosew, rzeczywiście się pojawiają u niektórych przedstawicieli młodej inteligencji. Jednak wielki kwantyfikator, używany w odniesieniu do mentalności ludzi tamtej epoki, owocować musi błędem, gdyż tym, co zdaje się podlegać wymianie w interesującej nas epoce, nie jest intymna kolektywna „swojskość”, lecz typ nadrzędnej obcości, z którą - na mocy ,praw historii” (losu?) - należy ułożyć relację. Obcy dysponuje stosownymi dystynkcjami, które przynoszą pożądane efekty materialne i których posiadanie rozum praktyczny definiuje jako korzystne dla siebie (Bourdieu, 2009). O tym aspekcie podejmowania decyzji przez „lud bez historii" Kiosew nie wspomina.

${ }^{5}$ Termin Kosellecka, określający ten okres w rozwoju kultury, który wiązał się ze zmianą semantyki pojęć (Widzicka, 2010, 45-58). 
O kolejnej nadinterpretacji można mówić w odniesieniu do refleksji badacza na temat Słowianobułgarskiej historii (1762) Paisija Chilendarskiego. To kanoniczne dla kultury bułgarskiej dzieło mentalnie zanurzone było w średniowieczu i tylko we wstępie zawierało pogłosy zapośredniczonej myśli oświeceniowej. Paisij korzystał m.in. z rosyjskiego wydania dzieła Cesare Baronio Annales Ecclesiastici a Christo nato ad annum 1198, opartego na wersji polskiej opracowanej przez ks. Piotra Skargę i opatrzonej jego wstępem, w którym nawoływał do studiowania historii. Paisij posłużył się tym fragmentem niemal dosłownie (Korwin-Szymanowski, 1981, 8-9). Badacze bułgarscy z reguły nie poświęcają tej sprawie zbyt wiele uwagi, a stanowi ona fascynujący przykład zapoznanej wędrówki idei. Tym bardziej że sto lat po swoim powstaniu owe fragmenty kompilacji Paisja zostały uznane za fundament bułgarskiej idei narodowej - dzięki XIX-wiecznym mitotwórcom szukającym rodzimej i zarazem odległej genezy dla procesów, których sami byli aktorami. Poczynania Marina Drinowa w tym zakresie można interpretować jako pierwszą udaną próbę kamuflażu źródeł bułgarskiej modernizacji, którego celem była ekspozycja „samorodności” bułgarskich tendencji oświeceniowych, oparta na przemilczeniu impulsu osmańskiego, ale także (choć w mniej radykalny sposób) - serbskiego i greckiego. W artykule Отец Паисий. Неговото време, неговата история и учениичие му (1871) Drinow poddał tę postać teleologicznemu uwzniośleniu, a jego interpretacja pozostawała kanoniczna aż po symbolicznie rozumiany 1989 rok. Kiosew, podważający tę wersję tzw. polityki historycznej, także nie odrzucił tezy o fundatorskim dla epoki „odrodzenia narodowego” charakterze historii Paisija, co w latach 90. XX wieku czynili już inni badacze (Трендафилов,1996). Dokonał natomiast istotnego przesunięcia aksjologicznego i w duchu psychoanalitycznej hermeneutyki podejrzeń przypisał dziełu mnicha nie (jak dotąd głoszono) pozytywny, lecz negatywny wpływ na mentalność Bułgarów. Synchronizując interpretację Słowianobułgarskiej historii z koncepcją samokolonizacji, Kiosew pominął fakt, że karcący rodaków za nieuctwo i nawołujący do poznawania ojczystej historii mnich każde naśladownictwo obcych wzorów uważał za prowadzące Bułgarów do zatracenia. W jego przypadku można więc mówić o inspirowaniu powrotu do swojskości przez porzucenie cudzych wzorów, które przyjmują „dzisiejsi mądrale, których ty masz w poważaniu i podziwiasz, i wleczesz się za ich 
językiem i obyczajami” (Paisij, 1981, 15). Paisij zatem negatywności nie ustanawiał, lecz ubolewał nad jej istnieniem i szukał antidotum. Genealogia fundacyjnego „braku” przesuwa się tym samym w jeszcze dalszą przeszłość... Z kolei późniejsze lamenty nad „brakiem”, które siedemdziesiąt lat po Paisiju wprowadził do publicystyki Konstantyn Fotinow (Фотинов, 1969, 320), są świadectwem innego rodzaju wrażliwości, ukształtowanej w tyglu XIX-wiecznej dynamiki życia, podróży, misji religijnych, wojen, wynalazków technicznych etc. Powolny proces modernizacji imperium pozwalał zresztą na stopniową anihilację owych „braków”: powstawały szkoły, literatura, zalążki teatru, malarstwa, wywalczono autokefalię (1870), wreszcie - państwo narodowe (1878).

Świadom niedostatków metafory samokolonizacji Kiosew, odrzucił ją przede wszystkim z powodu jej predyspozycji do generowania resentymentów. W jej miejsce wprowadził inną, nie mniej pod tym względem ryzykowną, w której w nowym sztafażu i w spauperyzowanej wersji powróciła heglowska metafora pana i niewolnika:

Отказът от тази метафора трябва да демонстрира само едно - че се отказваме от позицията „свое-чуждо“, за да мислим по не-ресантиментален начин. И да видим, че не „самите“ травматични култури си нанасят това дълбинно, себе-отчуждаващо нараняване - а че самата им „самост“ възниква в един глобален, асиметричен процес на модернизация, в който локалните колективи на предмодерната епоха се оказват структурирани по няколко напълно различни начина [wyróżnienie - G.Sz.-G.]. И под травматичната стратегия на писане трябваше да действува една друга теоретическа и в известен смисъл терапевтична стратегия, описваща не болезнената история на своето - а по-скоро един аспект от общата история на Модерността. Става дума за сдвоеността на нарцистичната (централната) и на травматичната (периферна) колективна идентичност, едновременното им възникване в тяхната структурно обусловена, генеалогическа вкопченост една в друга (Кьосев, 1998, 19).

Poszukując genealogii nowoczesności, badacz zobrazował ją jako strukturę będącą splotem pozostających w interakcji kultur „narcystycznych" (centralnych) i ,traumatycznych” (peryferyjnych), które łączy moment powstania, współistnienie i współoddziaływanie, ale dzieli wszystko, co ma związek ze sposobem przeżywania świata. W ujęciu tym doszło do tego, przed czym swego czasu przestrzegał Marc Bloch - utożsamienia rodowodu z wyjaśnieniem (Bloch, 1962, 57). W tym wypadku zdawało się ono pragmatycznie i politycznie motywowane. 


\section{Funkcja}

Hans G. Gadamer w książce o genezie filozofii podkreślał, że myślenie historyczne często popada w pułapkę określania początku z perspektywy czegoś, co brane jest za finalne (Gadamer, 2008, 23-26) ${ }^{6}$ :

Zachodzi tu potrzeba precyzyjnego ustalenia, iż coś jest początkiem tylko w odniesieniu do końca lub celu. Między nimi oboma - między początkiem i końcem - zachodzi nierozerwalny związek. Początek zawsze niesie ze sobą myślenie o końcu. Kiedy nie określa się wyraźnie, do czego odnosi się obecny w wypowiedzi początek, mówi się coś pozbawionego sensu. Koniec określa początek, a przez to wikłamy się w szereg trudności. Antycypacja końca jest warunkiem konkretnego znaczenia początku (Gadamer, 2008, 23).

Presja współczesności powoduje zmienność wizualizowanych form owego początku, który bywa modyfikowany teleologicznie z uwagi na swój domniemany koniec. Czy zatem oba koncepty Kiosewa można uznać za odzwierciedlenie urazów małego narodu, pod koniec XX wieku głęboko zranionego doświadczeniami nie tyle swych początków, ile licznych transgresji kulturowych: niedokończonej modernizacji w duchu zachodnim, sowietyzacji, desowietyzacji, nowej okcydentalizacji, dziś zakłócanej przez zwolenników cywilizacji spod znaku „руский мир”? W uformowanym przez badacza świecie źródłem dyskomfortu okazuje się sama struktura nowoczesności, w której zmieniający się „narcystyczni” hegemoni cywilizacyjni przez sam fakt swojego istnienia prowokują wspólnoty „traumatyczne” do kolejnych prób sprostania ich standardom. Czy wobec tego mentalne predyspozycje tych wspólnot nie zostały raz na zawsze zdeterminowane przez zły początek?

Na pytanie o determinizm w sferze rzeczywistości kulturowej Gadamer odpowiada negatywnie, kładąc nacisk na radykalną odmienność świata intelektu i przyrody:

Rozwój jest, ściśle określając, negacją historii. Rozwój oznacza, że wszystko od początku jest dane - wszystko jest zwinięte w początku (...) „rozwój” nosi w sobie zawsze naturalistyczne piętno. (...) Pojęcie rozwoju wyraża zatem zasadniczą odmienność, jaka istnieje między niezmiennością procesów przyrody i wynikającą z przypadku i zdarzenia chwiejnością życia ludzkiego. Tu właśnie wyraża się najbardziej pierwotna sprzeczność między przyrodą i intelektem (Gadamer, 2008, 24).

${ }^{6}$ Wśród polskich badaczy na ten aspekt pracy historyka zwracało uwagę wielu uczonych, m.in. Jerzy Szacki czy Jerzy Jedlicki. 
We wspomnianym tu cyklu wykładów wygłoszonym we Włoszech w 1988 roku, Gadamer przedstawił przegląd podstawowych błędów, które mogą towarzyszyć historycznym rekonstrukcjom początków. Za najważniejsze uznał ignorowanie przedsądów badacza wynikających z jego zanurzenia $\mathrm{w}$ tradycji oraz niedocenianie historycznej zmienności semantyki badanych kategorii ${ }^{7}$. Zatem, by zbliżyć się w najpełniejszy możliwy sposób do przedsokratejskich źródeł filozofii, Gadamer ${ }^{8}$ zdecydował się szukać śladów owego prapoczątku w dialogicznie rozumianej myśli późniejszych filozofów. Przyjmując wstępne założenie, że początek należy badać nie z perspektywy teleologicznej, lecz jako coś, co nie zostało jeszcze określone i pozostaje potencjalnością, Gadamer znalazł inspirację w myśli Diltheya i jego rozumieniu struktury jako „współdziałania oddziaływań” (Gadamer, 2008, 30), gdzie:

Faktem konkretnym jest spotkanie człowieka z samym sobą wobec Innego, różnego od niego samego. Jest to raczej uczestniczenie, które podobne jest w jakiś sposób do tego, co zachodzi w obliczu przesłania religijnego u wierzących, i nie powinno być traktowane jedynie, jako związek między podmiotem i przedmiotem, jak to się dzieje w naukach przyrodniczych (Gadamer, 2008, 38).

W ujęciu Gadamera relacja z Obcym nie może się obyć bez woli negocjowania sensów, opiera się na pracy intelektu. Tymczasem metafora samokolonizacji u Kiosewa, pochodna wobec myśli Saida, i koncept narcystyczno-traumatycznej genealogii nowoczesności odsyłają do sfery uczuć. Stanowią one rodzaj racjonalizacji reakcji emocjonalnej wspólnoty na determinanty psychologiczne, społeczne, historyczne, ekonomiczne. W tym sensie gest bułgarskiego badacza wydaje się repetytywny w stosunku do gestów XIX-wiecznych publicystów bułgarskich pozycjonujących swą kulturę na aksjologicznie wymodelowanej mapie świata. Materiał źródłowy pokazuje, że modne wówczas idee, takie jak „rozwój” czy „,ewolucja” służyć mogły i demokratycznemu niwelowaniu różnic, i budowaniu ich hierarchii. Na przykład pierwsi XIX-wieczni rzecznicy zmian pozycjonowali miejsce Bułgarów na mapie ,cywilizowanego świata”, utożsamiając rozwój nauki

${ }^{7}$ To z jego inspiracji niemiecki badacz Reinhart Koselleck podjął badania nad dziejami pojęć (Koselleck, 2009).

${ }^{8}$ Ze względu na to, że interesuje mnie tu studium przypadku, zatrzymuję się przy książce H. Gadamera Początek filozofii, a nie przy jego fundamentalnym dziele Prawda i metoda. 
i oświaty z wprowadzaniem ładu moralnego (np. o. Neofit Bozweli czy inspirowany przez protestantów Konstantin Fotinow). Ich sposób rozumowania opierał się na chrześcijańskiej koncepcji metanoi, ale za wzór do naśladowania stawiali już nie Jezusa, lecz oświeconego Europejczyka. Przemiana pozostawała $\mathrm{w}$ tym ujęciu sprawą woli, celowego działania prowadzącego od nieporządku barbarii (lub pustki niebytu w późniejszej refleksji np. Neszo Bonczewa) ku porządkowi cywilizacji. Ilustruje to m.in. rosyjski podręcznik Кратко начертание на весеобща история от професор господина Ивана Кайданова, а от Росийският на Славено-болгарският наш язик преведено и в най-новата история допалнено от Атанаса Стиловича Копиловскаго, урожениа Казанскаго в Болгарии, и посвященно господину Йоанну Добрьову Х. Бакалоглу (1836), który powielał obiegowy koncept linearnego rozwoju Europy i w ten sposób zdejmował z Bułgarów odium wyjątkowości. Zarazem jednak Bułgarom (Heglowskiemu ,narodowi bez historii”) w kompendiach historycznych nie poświęcano uwagi. Ich głód wiedzy o sobie samych (,,narcyzm”?) częściowo zaspokajały deskryptywne podręczniki do geografii, zwykle tłumaczone z rosyjskiego czy francuskiego. Zawarte tam informacje demograficzne o Bułgarach jako słowiańskojęzycznych poddanych sułtana i mieszkańcach Europy w pewien sposób sprzyjały kształtowaniu ,godnościowego" modelu tożsamości (Груев, 1861, 75-76), niemniej stale przywoływana opozycja barbarzyństwa i cywilizacji nie ułatwiała im rozpoznania się w którejś z tych retorycznych figur ${ }^{9}$. Znamienne przesunięcia akcentów pojawiły się w latach 60 . XIX wieku wraz z przenikaniem na grunt bułgarski (za pośrednictwem Serbów i Rosjan) idei naturalistycznego determinizmu w historii. Pozwalały one oczekiwać koniecznych, zgodnych z odwiecznymi prawami rozwoju zmian, a zarazem wprowadzały swego rodzaju równouprawnienie co do ,złego początku”. I tak np. Dimitri Pisariew, którego przeróbka książki Johna W. Drapera A History of the Intellectual Development of Europe $(1862,1864)^{10}$ była podstawą wydania bułgarskiego (Дрепер,

${ }^{9}$ Geografia otrzymała, wraz z jej wprowadzeniem latach 30. XIX wieku do bułgarskojęzycznych szkół, stosunkowo wysoki status, o czym świadczy m.in. liczba wydanych w latach 1835-1874 podręczników (41, a wraz z reedycjami 55). Najbardziej popularnym był Géographie de l'abbé Gaultier (1841, bg. wydanie 1855).

${ }^{10}$ Dzieło popularne było w Rosji, Iranie i imperium osmańskim. Wśród frankofonów osmańskich krążył francuski przekład książki, powstawały też przekłady arabskie (Werner, 2004, 7-27). 
1875), prezentował Anglię, Francję i Niemcy jako ojczyznę ludzi niegdyś „brutalnych i podobnych do zwierząt”, którzy w wyniku procesu dziejowego stworzyli kulturę „sztuczną, teatralną i bałwochwalczą” (Mishkova, 2004, 183-200). Zły początek generował złe kontinuum i na mocy kontrastu dostarczał Draperowi argumentów na rzecz dowartościowania świata nieeuropejskiego. Najbardziej konsekwentny w Bułgarii propagator myśli Drapera - Luben Karawełow, podchwycił wyobrażenie kultur powiązane z cyklem życia (Каравелов 1867-1868). Dostarczało ono takich skojarzeń jak gnicie, regres. Śmierć jednych kultur obiecywała rozwój innych: młodych, zdrowych, energicznych. W tym samym paradygmacie mieściły się późniejsze projekty ezoteryczne rozwijające teozoficzną koncepcję duchowej i fizycznej ewolucji ludzkości, która miała znaleźć swoje zwieńczenie w nastaniu rasy ludzi doskonałych. Wpływy Darwina czy Chamberlaina w nauczaniu twórcy Białego Bractwa Petyra Dynowa wyrażały się w zwrocie ku determinizmowi (w tym wypadku biologicznemu i kosmicznemu), który służył budowaniu obrazu geokulturowej niezależności Bułgarów, wiodących prym wśród Słowian i nieskalanych dopóty, dopóki polegają tylko na własnych źródłach. W ten oto sposób antyeuropejskie przesądy Drapera, przefiltrowane przez wrażliwość estetyczną, moralną i polityczną kultur-pośredników, okazywały się jedną z możliwych odpowiedzi na pytania dręczące Bułgara w sytuacji jego własnej niepewności kulturowej. Meandry transferu idei dokumentują istnienie postaw inteligencji bułgarskiej politycznie i światopoglądowo uwikłanych oraz dalekich od fetyszyzowania Zachodu, choć do jego osiągnięć odnoszono się z respektem. Nadzieję na przyszłość wiązano jednak z czymś tak wewnętrznie sprzecznym, jak ,,prawo rozwoju historycznego" i jego nieubłagane mechanizmy. Co więcej, ów pseudonaukowy, naiwny determinizm zdawał się korespondować z ludowym fatalizmem, w tym przypadku niosącym pociechę, co powinno zostać przez badaczy na nowo przemyślane.

Trudno nie zgodzić się $\mathrm{z}$ tezą, że w praktyce kolonizatorskiej idea ewolucji, z jej sztandarowym determinizmem i hierarchią bytów ${ }^{11}$, stawała się narzędziem symbolicznej dominacji i legitymizacji władzy. Jednak na gruncie XIX-wiecznych zmagań Bułgarów z własnym historycznych dziedzictwem posługiwano się nią w sposób niejednoznaczny, co może być

${ }^{11}$ Ową hierarchię historyk idei Arthur Lovejoy prezentował jako przewrotną interpretację starożytnego konceptu wielkiego łańcucha bytu (Lovejoy, 1999). 
jednym z dowodów na polisemantyczność bułgarskiego początku nowoczesności. Sam Kiosew, pisząc o ograniczeniach podejścia teleologicznego, ostatecznie stanął po stronie heterogeniczności źródeł, które wymykają się racjonalizacjom historyków (Кьосев, 1998, 48). Wśród nich koncept samokolonizacji pozostaje wartą uwagi ilustracją mechanizmu uruchamiania spekulatywnej wyobraźni naukowej czerpiącej z zasobów myślenia potocznego ${ }^{12}$. W efekcie wykreowana przez Kiosewa dwuwariantowa wizja kultury bułgarskiej jako „struktury traumatycznej” wydaje się misternie skonstruowaną i sfunkcjonalizowaną symulacją, w której patologiczny początek generuje reprodukowanie w historii wciąż tego samego wzoru kultury jako formy istnienia nie dość autentycznego, przeregulowanego z powodu niedostosowania do funkcji, które ma pełnić. Sytuację tę zdaje się dobrze obrazować opisane przez patomorfologów zjawisko symmorfozy (Szarski, 1988, 381-383). W przypadku złożonych organizmów biologicznych polega ono na przejmowaniu w sytuacji kryzysowej funkcji chorego organu przez inny. Wymuszona zmiana prowadzi nie tylko do przeregulowania charakteru współoddziaływań danego narządu z innymi elementami układu morfologicznego, ale także do zmiany jego struktury (Weibel, 2000). Pod piórem Kiosewa traumatyczna genealogia, której rekonstrukcja staje się wyjaśnieniem teraźniejszości, okazuje się hegemonem przejmującym całość funkcji kulturotwórczych. Symulowany początek urasta do roli czynnika determinującego dalsze przeobrażenia, staje się matrycą powielaną w nieskończoność... Pamiętamy, że ta interpretacja, wyrastająca z potrzeby holistycznego ujęcia specyfiki kultury bułgarskiej i aspirująca do rangi konceptu emicznego, przez samego badacza została uznana za gest pusty. Na mocy paradoksu jednak stanowi ona interesujące świadectwo występowania afektu w badaniach literackich, który wyraża się w formie niezgody na ustanowiony kanon kultury narodowej, a zarazem utrudnia wyrwanie się spod presji zewnętrznych autorytetów i ich dystynkcji. Z założenia obrazoburcza wobec tradycji kluczowej, niosąca wymowę polityczną i terapeutyczną (Кьосев, 1998, 19), koncepcja ta okazała się przede wszystkim dokumentem tego, czym być nie chciała: predylekcji do zadomowionego na gruncie bułgarskim zwyczaju

${ }^{12} \mathrm{O}$ sile takiego oddziaływania w odniesieniu do nauk biologicznych pisał swego czasu Ludwik Fleck w książce Powstanie i rozwój faktu naukowego (1931, wyd. pol. 1986). 
interpretowania własnej kultury w języku, który czerpie swój prestiż nie $\mathrm{z}$ rozpoznania tego, co w niej najwartościowsze, lecz z degradowania tego, co i tak budzi kontrowersje.

\section{Literatura}

Bloch, M. (1962). Pochwała historii, czyli o zawodzie historyka. Przeł. Wanda Jedlicka, przedm. Witold Kula. Warszawa: PWN.

Bourdieu, P. (2009). Rozum praktyczny. O teorii działania. Przeł. J. Stryjczyk. Kraków: Wydawnictwo Uniwersytetu Jagiellońskiego.

Fleck, L. (1986). Powstanie i rozwój faktu naukowego. Przeł. M. Tuszkiewicz, wstęp Z. Cackowski. Lublin: Wydawnictwo Lubelskie.

Gadamer, H.G. (2008). Poczatek filozofii. Przeł. J. Gajda-Krynicka. Warszawa: IFiS PAN.

Kantorowicz, E. (2007). Dwa ciała króla. Studium ze średniowiecznej teologii politycznej. Przeł. M. Michalski, A. Krawiec, red. nauk. wyd. pol. J. Strzelczyk. Warszawa: PWN.

Kasprzyk, Z. (2000). Samokolonizacja albo eurobatwochwalstwo. „Fronda”, nr 21/22, s. $196-199$.

Kiosew, A. (2000). Uwagi o samokolonizujących się kulturach. Przeł. E. Solak. „Dekada Literacka", nr 9/10, s. 14-15.

Kiossev, A. (1999). Notes on Self-Colonizing Cultures. W: After the Wall: Art. And Culture in post-Communist Eyrope. Red. B. Pejic, D. Eliot. Stockholm. http://ica. cult.bg/images/razni/File/A_Kiossev_en.doc. 22.01.2016.

Korwin-Szymanowski, F. (1981). Stowo wstęne. W: Paisij Chilendarski. Stowianobułgarska historia. Przeł. i wstępem opatrzył F. Korwin-Szymanowski. Warszawa: Czytelnik, s. 5-11.

Koselleck, R. (2009). Dzieje pojęć. Studia z semantyki i pragmatyki języka społeczno-politycznego. Przeł. J. Merecki, W. Kunicki. Warszawa: Oficyna Naukowa.

Lovejoy, A.O. (1999). Wielki łańcuch bytu: studium z dziejów idei. Przeł. A. Przybysławski. Warszawa: „KR”.

Mishkova, D. (2004). Europe In the Nineteenth-Century Balkans: A Case Study in the Cultural transfer of Concepts. „Revue des études sud-est éuropeennes”, XLII, nr $1 / 4$, s. $183-200$.

Paisij Chilendarski (1981). Stowianobułgarska historia. Przeł. i wstępem opatrzył F. Korwin-Szymanowski. Warszawa: Czytelnik.

Sowa, J. (2011). Fantomowe ciało króla. Peryferyjne zmagania z nowoczesna forma. Kraków: Universitas.

Symmorphosis. http://www.encyclopedia.com/doc/1O6-symmorphosis.html. 20.02.2016.

Szarski, H. (1988). Nowe pojęcie morfologii porównawczej, symmorfoza. „Przegląd Zoologiczny", t. 32, nr 3, s. 381-383. 
Szwat-Gyłybow, G. (2005). Haeresis bułgarica w bułgarskiej świadomości kulturowej XIX $i$ XX wieku. Warszawa: SOW.

Weibel, E.R. (2000). On Form and Function in Shaping Life. http://www.hup.harvard. edu/results-list.php?author=2974. 10.12.2015.

Werner, W. (2004). John William Draper i Andrew Dickson White wobec wojny nauki z religia. Rola metafory historiograficznej. „Kwartalnik Historii Nauki i Techniki”, nr 1, r. 49, s. 7-27.

Widzicka, M. (2010). Semantyka historyczna w ujęciu Reinharta Kosellecka. Zarys problematyki. „Historyka”, t. XL, s. 45-58.

Бончев, Н. (1969). Класическите европейски писатели на български език и ползата от изучаването на съчиненията им (Поради повестта „Тарас Булба”). W: Възрожденски страници. Антология, t. 2. Red. П. Динеков. София: Български писател, s. 507-508.

Груев, Й. (1861). Уроци от землеописание от Й. Груева. Виена: Книгопродавница Л. Сомера.

Дрепер, Д. (1875). Съкратена история на умственото развитие в Европа. Przeł. А. Илиев. Цариград: Печатницата на Карапетров.

Дринов, М. (1909). Отеи Паисий. Неговото време, неговата история и ученииите My. W: Трудове на М.С. Дринова, t. 1. Red. В. Златарски. София: Българско книжовно дружество, s. 113-137.

Каравелов, Л. (1985). Сръбската литература. W: Събрани съчинения в 12 m., t. 6. София: Български писател, s. 47-84.

Кратко начертание на всеобща история от професор господина Ивана Кайданова, а от Росийският на Славено-болгарският наш язик преведено и в най-новата история допалнено от Атанаса Стиловича Копиловскаго, урожениа Казанскаго в Болгарии, и посвященно господину Йоанну Добрьову Х. Бакалоглу. (1836).

Кьосев, А. (1998). Списъии на отсъствието. W: Българския канон. Кризата на литературното наследство. Red. А. Кьосев, София: Изд. къща Ал. Панов, s. $5-49$.

Трендафилов, В. (1996). Паисий-неконструктор, а конструкт на Възраждането. http://liternet.bg/publish8/vtrendafilov/za_ramkite/paisij.htm. 16.03.2016.

Фотинов, К. (1969). Предисловие любочитателем (,Любословие”, 1844). W: Възрожденски страниии. Антология, t.1. Red. П. Динеков. София: Български писател, s. 319-323.

Хилендарски, П. (1972). История славяноболгарская: Първи софрониев препис om 1765 година. Red. Б. Райков. София: Наука и изкуство. 